\title{
0 apoio Paideia como metodologia para processos de formação em saúde
}

Mariana Dorsa Figueiredo(a)

Gastão Wagner de Sousa Campos(b)

Figueiredo MD, Campos GWS. Paideia support as a methodology for healthcare education processes. Interface (Botucatu). 2014; 18 Supl 1:931-43.

This paper analyzes Paideia support as a pedagogical framework for healthcare education processes, with a design combining theoretical offers, case discussion and interventions. We analyzed the effects of this process on the participants' practices, with regard to subjective approaches. The empirical material was constructed from focus groups, analysis of a clinical case and discussions with the team responsible for the case. Changes in clinical practice, management and "self-management" were observed. These professionals have developed technical, ethical and relational expertise for working on the multiple dimensions of the subjects. It was concluded that the emphasis on exchanges of experiences and on linkages between reflection and action contributes towards producing changes in the subjects, practices and healthcare services.

Keywords: Paideia method. Institutional support. Education. Expanded clinical practice. Subjectivity.
Este artigo analisa o apoio Paideia como referencial pedagógico num processo de formação em saúde, cujo desenho combinou ofertas teóricas, discussão de casos e intervenções. Avaliamos os efeitos desse processo formativo nas práticas dos participantes, no que se refere à abordagem da subjetividade. O material empírico foi construído a partir de: grupos focais; análise de um caso clínico; e discussão com a equipe responsável pelo caso. Observaramse mudanças nas práticas clínicas, de gestão, e na "gestão de si". Os profissionais desenvolveram competências técnicas, éticas e relacionais para atuarem nas múltiplas dimensões dos sujeitos. Concluise que a ênfase na troca de experiências e na articulação entre reflexão e intervenção contribui para que a formação produza mudanças nos sujeitos, nas práticas e nos serviços de saúde.

Palavras-chave: Método Paideia. Apoio institucional. Formação. Clínica ampliada. Subjetividade. (a,b) Departamento de Saúde Coletiva, Faculdade de Ciências Médicas, Universidade Estadual de Campinas (Unicamp). Rua Tessália Vieira de Camargo, 126, Cidade Universitária Zeferino Vaz. Campinas, SP, Brasil. 13083-887. madorsa@hotmail. com; gastaowagner@ mpc.com.br 


\section{Introdução}

Apesar dos avanços na ampliação do direito e do acesso à saúde no SUS, ainda permanece o desafio de qualificar e legitimar a assistência, buscando a produção de saúde de forma integral e resolutiva. Uma das diretrizes, nesse sentido, é a construção de uma clínica ampliada e compartilhada ${ }^{1-3}$, que pressupõe: 1) tomar como objeto de trabalho não somente a doença, mas o sujeito em sua existência; 2) tomar como objetivos do trabalho, além da cura, reabilitação e prevenção, o desenvolvimento da autonomia; 3) compor o diagnóstico, considerando não só o saber clínico e epidemiológico, mas a história e os saberes do sujeito; 4) definir a terapêutica, considerando a complexidade biopsicossocial; 5) construir relações baseadas no diálogo, na negociação, no compartilhamento do saber e do poder, no vínculo e na responsabilização; 6) trabalhar em equipe e em rede.

Entretanto, o enfoque técnico e centrado no paradigma biomédico dos cursos de graduação, assim como a insuficiência de instâncias de formação permanente nos serviços, não têm possibilitado a qualificação dos profissionais para analisarem a complexidade das dimensões constitutivas dos sujeitos, tampouco para operarem com essa concepção clínica. Diversas pesquisas ${ }^{4-6}$ demonstram as dificuldades enfrentadas pelos profissionais na abordagem da dimensão subjetiva que toda prática em saúde supõe, por encontrarem-se sem arcabouço teórico e prático.

Assim, faz-se necessário investir em propostas de formação permanente para os profissionais do SUS, que aportem uma visão ampliada do processo saúde-doença-intervenção e que os qualifiquem tanto para lidar com o universo emocional, simbólico e sociocultural dos sujeitos, como para compreender a prática clínica como prática inter-relacional e operar com os fluxos de afeto e poder.

Este artigo descreve uma pesquisa realizada no âmbito de um Curso de Especialização com caráter de intervenção institucional, que foi oferecido, pela Faculdade de Ciências Médicas da Unicamp, para profissionais da Atenção Básica do SUS-Campinas (SP). O curso adotou como referencial pedagógico a concepção teórica Paideia e sua metodologia de apoio à cogestão de coletivos ${ }^{1}$. A partir da análise do uso do apoio Paideia nesse curso, pretende-se contribuir para a formulação de propostas de formação permanente aos profissionais do SUS, como dispositivos para a produção de mudanças nos sujeitos, nas práticas e nos serviços de saúde.

\section{O apoio Paideia: formação como prática, prática como formação}

Historicamente, a formação dos profissionais de saúde tem sido pautada pelo modelo de educação positivista, que tende a fragmentar o conhecimento e a reduzir o saber à busca pela eficiência técnica. O conhecimento, nessa lógica, é visto como produção estática, como verdade que está no mundo para ser descoberta. Dessa forma, os processos de ensino-aprendizagem se restringem à transmissão do conhecimento de um sujeito que o detém para outro que o retém e deve repeti-lo ${ }^{7,8}$.

A consolidação de políticas públicas para garantia de cidadania exige outro modelo de educação, que estimule a construção da consciência crítica, da curiosidade criativa e indagadora de um sujeito que reconheça a realidade como mutável e busque transformá-la. Além disso, o trabalho em saúde se dá essencialmente por meio da relação entre pessoas. Portanto, a visão de mundo, os valores, a postura ético-política e os afetos do profissional comparecem em suas intervenções ${ }^{9}$. Sendo assim, devem ser tomados como objeto juntamente com os aspectos técnico-científicos no processo de formação. O desenvolvimento do SUS depende da formação de profissionais com competências técnicas, mas também ético-políticas e relacionais; com capacidade crítica e sensibilidade para pensar as questões da vida e da sociedade, e para atuarem em contextos de incerteza e complexidade ${ }^{10}$.

Para isso, a metodologia dos processos de formação deveria imbricar teoria e prática, estudo e intervenção, partindo das experiências e dos problemas concretos para desenvolver a capacidade de reflexão e ação dos sujeitos. Como referencial pedagógico para esse modelo de formação, propõe-se o método Paideia, uma rede conceitual e operativa desenvolvida por Campos ${ }^{1}$ para o trabalho com coletivos. 
O apoio Paideia é a metodologia para operacionalizar essa rede de conceitos e possui vários eixos de aplicação. Pode ser utilizado na gestão (apoio institucional); nas relações interprofissionais (apoio matricial); e na relação clínica (clínica ampliada e compartilhada). Nos últimos anos, o apoio Paideia também tem sido utilizado como metodologia para a formação em saúde ${ }^{11-13}$.

Segundo Campos ${ }^{1}$, o trabalho possui um triplo objetivo: trabalha-se para produzir valor de uso para terceiros; trabalha-se para si mesmo, para assegurar a própria existência social; e trabalha-se para a reprodução da própria organização. Dessa forma, além dos aspectos administrativos e financeiros, a gestão deveria considerar os aspectos políticos, pedagógicos e subjetivos que constituem os processos de trabalho, isto é, seriam objetivos da gestão a produção de bens ou serviços, mas também a produção dos sujeitos e coletivos. Ademais, o trabalho se exerce entre sujeitos com distintos graus de conhecimento e poder, o que torna indispensável a construção de espaços coletivos em que as equipes possam elaborar projetos comuns e lidar com os conflitos e diferenças por intermédio da construção de contratos.

O objetivo do Método seria interferir no contexto institucional, visando efetivar a gestão democrática (cogestão) e ampliar a capacidade dos sujeitos para analisar, tomar decisões e agir sobre a realidade.

Resgatando o pensamento de Aristóteles, Campos ${ }^{14}$ afirma que o trabalho em saúde é o exercício de uma práxis, já que se dá por meio de relações entre sujeitos, e por isso não pode se desvincular da análise da singularidade do contexto. Ao contrário do saber técnico, em que o conhecimento prévio dispensaria reflexão ou deliberação, na práxis o sujeito não pode se isentar da reflexão e da prudência: ele deve considerar o conhecimento acumulado, mas equacioná-lo na situação singular, considerando os sujeitos envolvidos, os diferentes valores e conjunturas.

Toda práxis é uma atividade de transformação de dadas circunstâncias, que nos conduzem a formar novas ideias, que por sua vez nos auxiliam a criar novas circunstâncias. Portanto, a formação de pessoas para a transformação do trabalho em saúde deve operar concomitantemente os sujeitos e as instituições. Considerando que a transformação das pessoas e do trabalho dá-se por meio da elaboração reflexiva das experiências de interação dos sujeitos com o mundo, a formação deveria incluir tanto o pensamento como a ação.

\section{A função "apoiador": suporte e impulso}

O termo apoiador pretende enfatizar a noção de suporte, amparo, auxílio, mas também a noção de impulso para o movimento. $O$ apoiador deve oferecer suporte à constituição do coletivo, facilitando a interação e reflexão. Mas, ao mesmo tempo, deve ofertar novos conceitos, categorias e recursos, empurrando o grupo para atingir seus objetivos ${ }^{15}$. Seja ele um apoiador institucional, matricial ou um apoiador num processo formativo, seu trabalho é ajudar o grupo a analisar seus dilemas e impasses, com um compromisso de passar da análise e da crítica para a intervenção na realidade.

O apoiador está implicado com certo projeto técnico e político e traz consigo seus posicionamentos a respeito do ideal de um sistema de saúde, dos modelos assistenciais e de gestão. Assim, ele deve considerar as diretrizes institucionais e clínicas, os resultados da atividade prática e dos processos de trabalho. Ele autoriza-se a trazer olhares distintos que permitam abalar as verdades instituídas e contribuir para mudanças nos modos de pensar e agir. Porém, ao invés de impor essas questões, coloca-as em debate para que o grupo exerça a cogestão.

Nesse sentido, destaca-se como característica fundamental do apoio Paideia a combinação da demanda do próprio grupo com as ofertas trazidas pelo apoiador, tanto na eleição dos temas a serem analisados, como nos próprios elementos a considerar na análise e na definição das propostas de intervenção.

A noção de oferta pretende enfatizar a necessidade de apoiar o grupo a confrontar-se com o externo, com o diferente e, a partir disso, exercitar sua capacidade de cogestão. Assim, trabalha-se tanto a partir de temas relacionados aos interesses do grupo, como outros decorrentes do contexto social trazidos pelo apoiador, que podem ser informações, protocolos, diretrizes, perspectivas distintas 
do grupo, categorias de conhecimento e, especialmente, a própria rede operativa de conceitos do método Paideia e o modelo de atenção e gestão nele proposto.

A valorização da oferta tem o intuito de produzir situações que obriguem o grupo a se pronunciar sobre metas e objetivos da instituição, assim como representações oriundas de outras instâncias, de modo a abrir "janelas" por onde o grupo possa recompor desejos, interesses e projetos.

\section{Como fazer apoio?}

Um grupo de apoio Paideia deve ocorrer num espaço coletivo: um lugar e um tempo que possibilite encontros periódicos entre os profissionais, de modo que consigam refletir e intervir sobre a prática.

Nesse espaço coletivo, o apoiador deve contribuir para a construção de uma grupalidade que permita às pessoas se identificarem, em graus distintos, como pertencentes ao grupo e compartilharem um objetivo ou projeto. Com um contrato de funcionamento do grupo, deve-se criar uma condição de espaço protegido, onde o grupo pode depositar confiança para falar de sua prática e expor seus questionamentos e dificuldades.

A dinâmica dos encontros baseia-se na estratégia de discussão de casos reais ou temas de interesse do grupo e relevantes ao contexto. Em cada encontro se analisa um caso ou tema e se define tarefas que o grupo deverá desenvolver, exercitando sua capacidade de intervenção. A tarefa pode ser desde a busca novas informações, até um projeto de intervenção estruturado, que envolva vários atores e a modificação de dada situação. Então, no encontro seguinte, o grupo faz novo movimento: avalia o resultado das ações, volta a analisar a situação ante às novas informações e redesenha o plano de intervenção.

A estratégia de discussão de casos pretende estimular os profissionais a falarem da prática concreta, o que possibilita analisar o que é coproduzido na instituição e o que se passa na relação entre profissional, equipe e usuários. Entretanto, procura-se trabalhar com o sentido que o "caso" adquire na psicanálise. Para Nasio ${ }^{16}$, o caso em medicina remete ao sujeito anônimo que representa uma doença: diz-se, por exemplo, "um caso de tuberculose". Para a psicanálise, ao contrário, o caso exprime a singularidade do ser e da fala que ele nos dirige, ou seja, trata-se de "o caso", "o meu caso", implicando também a escuta dos diferentes profissionais que se relacionam com o sujeito.

Desse modo, o relato de um caso nunca é o reflexo fiel de uma situação, mas é uma reconstituição, uma história reformulada a partir da escuta e da subjetividade do profissional. Portanto, ao solicitar que os profissionais apresentem um caso para discussão, pretende-se focalizar a relação clínica, os afetos e conflitos que aí se estabelecem. Além dos aspectos técnicos envolvidos na condução do caso, interessa a reflexão sobre os motivos da escolha do caso, o modo como os profissionais lidam com os valores e sentimentos, o modo como a equipe se organiza para resolver as dificuldades.

Essa estratégia de formação, centrada na discussão de casos, foi desenvolvida por Balint ${ }^{17}$ na década de 1950, numa experiência com grupos de supervisão com clínicos gerais vinculados ao Sistema Nacional de Saúde da Inglaterra. Nesses grupos, Balint propunha a análise do que se passava na relação entre médicos e pacientes e dos aspectos inconscientes que influenciavam a evolução da doença e do tratamento. No apoio Paideia, a estratégia de discussão de casos foi ampliada em três sentidos ${ }^{12}$.

Primeiro, ampliou-se o entendimento sobre o que se configura como "caso". Balint preconizava o debate sobre casos clínicos e enfatizava a clínica individual (o trabalho médico na Inglaterra não se dava em contexto de equipe). No apoio Paideia incluem-se casos de Saúde Coletiva e institucionais, isto é, problemas comunitários, grupos de promoção à saúde e situações de ordem gerencial. Além disso, os casos podem ser apresentados por um único profissional ou por uma equipe, embora o tema da equipe seja central em todas as situações discutidas.

O segundo sentido de ampliação refere-se ao papel ativo do apoiador ao trazer ofertas. Balint trabalhava essencialmente com o que era trazido no relato dos casos, no que se referia às implicações psicológicas na clínica. No apoio Paideia, o apoiador oferta núcleos de análise não abordados pelo grupo, e temas teóricos sobre atenção à saúde, trabalho em equipe e organização do SUS, além de diretrizes, demandas e experiências de outras instâncias. 
Uma terceira ampliação refere-se à ênfase na prática concreta. Cada caso é apresentado, discutido e analisado, buscando-se uma compreensão coletiva sobre a situação singular e também sobre os temas que emergem da discussão e que podem ser generalizados em outras situações. Porém, na sequência, deve ser elaborado um conjunto de propostas de intervenção para orientar a resolução das dificuldades e conflitos. Essas propostas devem ser organizadas na forma de Projeto Terapêutico (para os casos clínicos) ou de Projeto de Intervenção (para os casos institucionais ou de Saúde Coletiva). Com isso, o caso, mais que um exercício de reflexão, transforma-se em um desafio que o profissional e sua equipe deverão levar à prática, avaliando, ao longo do processo, os avanços e dificuldades.

Assim como nos grupos operativos de Pichon-Rivière ${ }^{18}$, no apoio Paideia o saber (análise) aproxima-se do fazer (tarefas), possibilitando que do agir os sujeitos busquem teorias, conceitos, modelos para analisar e modificar, com certo distanciamento, a si mesmos e suas formas de ação. $O$ movimento de retomada da análise e do diagnóstico a partir da realização das intervenções permite criar uma diversidade de interpretações e assim modificar os sentidos já cristalizados pelos profissionais e afirmar as possibilidades de reconstrução social da realidade.

\section{Metodologia da pesquisa: o apoio Paideia num processo de formação em saúde}

A pesquisa realizou-se no âmbito do "Curso de Especialização em Saúde da Família: Atenção e Gestão do Cuidado na Atenção Básica", que foi oferecido pela Faculdade de Ciências Médicas da Unicamp para oitenta profissionais (médicos e enfermeiros) da Atenção Básica de Campinas (SP).

O curso combinou discussão de casos, práticas de intervenção e ofertas teóricas, de modo a estimular que, além da incorporação de novos conceitos, fossem desencadeadas intervenções nos serviços. Tratam-se, portanto, de inovações nos conteúdos teóricos, avançando na proposta de clínica ampliada e compartilhada, assim como no método de ensino-aprendizagem, utilizando discussões de casos reais e projetos de intervenção para institucionalização de novas práticas.

Foram compostas quatro turmas de cerca de vinte alunos. Cada turma foi acompanhada por uma dupla de apoiadores. O curso transcorreu num período de 18 meses, com encontros semanais de quatro horas de duração.

Em cada encontro semanal, um aluno trazia um caso para discussão. Com a mediação dos apoiadores, o grupo procurava analisá-lo em suas múltiplas dimensões (histórico do caso, intervenções já realizadas, relação entre os envolvidos). A discussão possibilitava que outros membros do grupo trouxessem suas experiências e formas diferentes de lidar com situações semelhantes. Também permitia fazer abstrações sobre a principal questão envolvida, momento em que os apoiadores traziam ofertas teóricas relativas à clínica, à Saúde Coletiva e à gestão.

Após a análise do caso, o grupo era estimulado a propor alternativas de ação, que deveriam ser levadas pelo aluno à sua equipe de trabalho, a fim de construírem um Projeto Terapêutico (para os casos clínicos) ou um Projeto de Intervenção (para os casos de Saúde Coletiva ou de gestão) e pactuarem ações que levariam adiante. Posteriormente, o aluno deveria reapresentar o caso e as intervenções, para que o grupo repensasse a situação à luz de novas informações, avaliando resultados e propondo outras ações.

A pesquisa foi realizada por uma das apoiadoras do curso, resultando em sua tese de doutoramento. Como unidade de análise, tomou-se uma das turmas, com o consentimento livre e esclarecido dos participantes e aprovação do Comitê de Ética da FCM/Unicamp. Tratou-se de uma pesquisa qualitativa que, como tal, é voltada para a compreensão dos significados que os sujeitos atribuem aos fenômenos ${ }^{19}$. O referencial metodológico baseou-se na hermenêutica crítica ${ }^{20,21}$, entendendo-a como uma postura interpretativa que busca a compreensão do sentido de um texto ou de um fenômeno humano, seja ele um discurso, um evento, uma cultura.

A pesquisa visou analisar os efeitos do uso do método Paideia nesse Curso de Especialização, para a formação e as práticas dos alunos, especificamente no que se refere à abordagem da subjetividade na clínica. Para tanto, teve como objetivos específicos: a) Analisar as contribuições do método Paideia na 
formação profissional; b) Investigar se o curso produziu mudanças na concepção sobre o processo saúde-doença, nas práticas clínicas e no trabalho em equipe; e c) Analisar as intervenções dos profissionais junto a um caso clínico discutido.

O trabalho de campo se deu durante o decorrer do curso. Foi utilizado um amplo leque de instrumentos para produzir triangulações ${ }^{22}$. Por um lado, além dos alunos, foram incluídos outros sujeitos que indiretamente acompanharam o curso, ampliando a polifonia do estudo. Por outro, utilizou-se diferentes instrumentos para a produção do material empírico, a fim de estabelecer conexões entre os discursos e as práticas efetivas. Essa multidimensionalidade permitiu ampliar o rigor e a validade das interpretações.

Os instrumentos agrupam-se em dois conjuntos de fontes de informação:

a) O material produzido no âmbito do próprio curso:

- Duas rodadas de grupos focais de avaliação do curso, com os alunos;

- Seleção de um caso clínico discutido, para aprofundar a análise.

b) O material produzido especificamente para a pesquisa:

- Mais duas rodadas de grupos focais com os alunos, para focalizar o tema da subjetividade na clínica;

- Discussão com a equipe de saúde responsável pelo caso selecionado, para reconstruir as intervenções realizadas;

Para a interpretação do material empírico, foi utilizada a abordagem narrativa ${ }^{23}$, compondo um enredo para dar sentido e coerência às falas dos sujeitos. Foram construídas narrativas a partir: das discussões feitas pelo grupo sobre o caso selecionado; da discussão com a equipe responsável pelo caso; e dos grupos focais com os alunos.

As narrativas foram processadas em categorias de análise, articuladas com as tradições teóricas utilizadas na pesquisa. As narrativas construídas a partir dos grupos focais com os alunos foram interpretadas em função de quatro categorias: clínica; gestão e trabalho em equipe; gestão de si mesmo; e metodologia do curso.

\section{Resultados: as construções da pesquisa}

\section{O reconhecimento da biografia de Dna. Ana}

O caso de Dna. Ana foi trazido por Arthur(c), médico de uma Unidade Básica de Saúde (UBS). Dna. Ana era uma mulher de 75 anos, mãe de 12 filhos. Ela era hipertensa, tomava os medicamentos irregularmente, morava sozinha e não

(c) Todos os nomes usados neste texto são fictícios. 
então, a expectativa de resolutividade na Atenção Básica e a necessidade de abordar múltiplos planos, como o sanitário, clínico, político, social, subjetivo.

Como propostas de intervenção, o grupo sugeriu: - Compreender a rede social e assistencial de apoio; - Fortalecer vínculos da paciente com alguém da equipe; - Restabelecer contato com familiares; - Propor atividades no Centro de Saúde ou no bairro; - Ajudá-la a descobrir coisas que dão prazer.

Seis meses depois, Arthur reapresentou o caso ao grupo. Uma de suas intervenções produzira grande mudança na relação com Dna. Ana. Arthur foi à casa dela, numa visita que chamou de "despretensiosa": foi apenas conversar, ouvir sua história de vida e, dessa forma, conseguiu aprofundar seu diagnóstico, incluindo nessa compreensão a dimensão emocional e social. Essa intervenção, embora aparentemente simples, contribuiu para que Arthur se colocasse como profissional de referência para Dna. Ana e isso foi dando outro contorno ao contato dela com a equipe como um todo.

Arthur também chamou um dos filhos dela para conversar, pretendendo ajudar na reaproximação familiar, de forma que alguém se responsabilizasse por algum cuidado. Os desdobramentos dessas intervenções puderam ser observados pela equipe durante outras visitas de rotina:

"O marido da neta estava pintando as paredes e trocaram alguns móveis. Dna. Ana estava serena, disse que não precisava daquilo, mas estava agradecida e feliz. Em outra visita Dna. Ana nos convidou a entrar, disse estar satisfeita com nossa preocupação. Nos abraçou na despedida". (Arthur)

Arthur também contou que o filho tem ido frequentemente à casa dela para lembrá-la de tomar os remédios para a hipertensão.

$\mathrm{Na}$ discussão sobre o acompanhamento do caso, o grupo identificou que a equipe ampliou sua capacidade de dialogar, negociar e conquistar participação da família e da própria paciente. Contribuiu para isso a existência de um espaço de equipe com reuniões periódicas no contexto da UBS, em que Arthur pôde levar as reflexões feitas no curso. O restante da equipe pôde analisar seus próprios afetos e a necessidade de compreender melhor as demandas de Dna. Ana. A disposição para ouvir e reconhecer a história de vida da paciente possibilitou que a equipe a acolhesse e, ao mesmo tempo, se sentisse mais satisfeita com o próprio trabalho:

"A equipe está mais tolerante. Percebemos que é preciso uma escuta e uma atuação menos impositiva e repreensiva. A equipe está se sentindo mais produtiva e útil. Menos angústia e mais resolutividade e união". (Arthur)

A própria equipe de Arthur teve oportunidade de trazer, para a pesquisa, o seu olhar sobre o acompanhamento do caso:

“Foi ação e reação: em pouco tempo a Dna. Ana teve uma melhora boa. Hoje ela é uma pessoa diferente daquela que pintava aqui na porta e a gente já saía gritando "socorro"... E isso a gente conseguiu através de muita conversa, mudamos a abordagem". (narrativa da equipe de Arthur)

Analisando os efeitos do curso, a equipe relata:

“Dr. Arthur mudou muito. Ele falava 'eu não gosto de reunião de equipe, ficar discutindo caso, não tenho paciência'. E agora ele volta estimulado, sempre nos mostra algo que a gente não está enxergando. Ele se empenhou e a equipe se contaminou. Até o coordenador voltou a participar de nossas reuniões". (narrativa da equipe de Arthur) 


\section{Os efeitos do curso: interpretando as narrativas sobre a clínica; a gestão e o trabalho em equipe; a gestão de si mesmo; e a metodologia do curso}

\section{Sobre a clínica: escutar, refletir, compartilhar}

Observou-se que os alunos adquiriram competências essenciais para a abordagem da subjetividade, dentre elas:

- A capacidade crítico-reflexiva:

Os alunos apontaram que muitas de suas intervenções eram baseadas em respostas prontas e automáticas, como forma de evitar o contato com o conflito e angústia. Um exemplo é a oferta da medicação como meio de aplacar as demandas não circunscritas ao biológico: "A gente acredita que tem o dever de dar uma resposta, e uma resposta, para nós, é quase sempre um remedinho. Isso é para que diminua a nossa angústia" (d). Outro exemplo são as intervenções pautadas por valores morais, conceitos e desejos do próprio profissional, e não propriamente pela demanda do usuário: "Você tenta ajudar mostrando uma maneira de resolver o problema, mas aquela é a 'sua' maneira. Muitas vezes precisamos ouvir e nos abrir para o que o outro traz".

Os alunos também referiram que o contato com os usuários pôde mobilizar "raiva e revolta", e que aprenderam a identificar e lidar com esses afetos a partir de um exercício reflexivo, que lança luz à clínica:

“Não existe um manual. É parar e refletir: 'opa, eu tô com raiva, não posso ficar assim'. Você aprende a lidar com os sentimentos e entender o ponto de vista da pessoa. Toda vez que o paciente nos desperta raiva, tristeza ou angústia, fazemos o retorno mais rápido, levamos para a reunião".

- A capacidade de escuta:

As narrativas assinalaram a compressão das demandas do usuário, por meio de recursos que extrapolam a clínica tradicional:

“Primeiro mostramos para o paciente que estamos abertos para ouvi-lo. Aprendemos a enxergar além daquilo que ele está dizendo, porque muitas vezes ele queixa de uma coisa e o problema é o que se esconde atrás. Fazemos isso visitando a casa, entendendo onde ele foi criado, a fé que ele tem, o meio em que ele vive e a família".

Além disso, os alunos fizeram referência a uma série de atitudes "aparentemente simples e pequeninas", mas que precisam ser constantemente lembradas e exercitadas:

"Receber o paciente na porta, fazê-lo se acomodar, tirar sua bolsa do colo... A empatia, o repousar a caneta na mesa e o olhar no olho... Ou quando o paciente está vindo muito ao serviço, perguntar o que está acontecendo, e aí vamos aproximando e aprofundando".

- A capacidade de compartilhar:

Os alunos pontuaram a singularização das intervenções e a combinação entre as demandas dos usuários e as ofertas terapêuticas:

(d) Todas as falas a seguir são referentes à narrativa dos alunos do curso, construída a partir das discussões nos grupos focais. 
“Às vezes fazemos uma proposta e o paciente não gosta. Aí tentamos entender e se for possível a gente negocia. Temos que abordar tudo, o biológico inclusive, mas se começamos por outra abordagem, ele vai confiando e percebe que estamos interessados nele e não só na pressão, no diabetes".

Foi destacada a importância da participação do usuário na composição do Projeto Terapêutico, como um fator decisivo para a resolutividade das intervenções, demonstrando um reconhecimento da dimensão do sujeito, em cada paciente e em si mesmos, como organizadora da clínica:

“Ele precisa estar junto senão ficamos propondo arrumar emprego, tentando vaga na creche, e na verdade o paciente não quer nada daquilo. E temos que estar preparados para ouvir que ele não quer. Nossa tendência é ficarmos indignados porque ele não quis o que sonhamos pra ele".

\section{Sobre a gestão e o trabalho em equipe: interfaces gestão-subjetividade}

Os alunos apontaram que o embasamento teórico sobre modelos de gestão lhes provocou questionamentos e maior capacidade de identificar equívocos no modo de organização do trabalho em seus serviços. Demonstraram ter se apropriado do que seria a finalidade da Atenção Básica, indicando que têm utilizado o repertório adquirido para demarcar posicionamentos:

"Se a gente sabe que visita domiciliar é essencial na Atenção Básica, a gente não deixa mais de fazer uma visita para atender o paciente que chegou com gripe. Isso o PS vai atender. Mas se eu não fizer essa visita, algum serviço vai fazer? É nossa prioridade, a gente tem que dar conta".

Observou-se avanços na constituição do trabalho em equipe, que foram provocadas pelas intervenções dos alunos:

“Estamos fazendo as reuniões serem mais centradas nos problemas. Insistimos que as coisas sejam levadas pra reunião. Se alguém está organizando um grupo, pedimos para levar pra equipe, para ser o grupo da equipe. Se a equipe entende aquilo, ela vai cuidar, vai nutrir. $\mathrm{E}$ nesse caminho a equipe vai virando uma equipe de verdade".

Os alunos apontaram a importância da elaboração de um projeto comum para propiciar que a equipe pactue os sentidos do trabalho. Além disso, indicam que esta é uma tarefa a ser feita permanentemente:

"Quando abraçamos a proposta da Saúde da Família, as coisas vão acontecendo. É claro que tem fases em que o pessoal está desmotivado. Aí a equipe tem que dar um chacoalhão: 'Vamos tentar de novo!' É um processo".

Os alunos referiram que o suporte à constituição da equipe é essencial e deveria ser composto nas instâncias de gestão. Em sua avaliação, essa função apoio deveria ser assumida pelo próprio gestor e, em alguma medida, pelo apoiador matricial da saúde mental ou pelo apoiador institucional. Foi apontada a necessidade de um lugar e um tempo para que esse apoio possa se dar, possibilitando que o processamento dos conflitos e das angústias seja configurado como material de trabalho da equipe: "que isso se desse num espaço legítimo, não na cozinha, na hora do café, para a equipe tomar decisões em conjunto e escolher as melhores intervenções".

A questão da sobrecarga e do desgaste dos profissionais apareceu em vários trechos das narrativas, tanto no que se refere ao contato com o sofrimento, a pobreza e a violência, quanto à pressão de uma demanda crescente e incongruente à capacidade do serviço. Os alunos destacaram o espaço coletivo 
como um espaço de produção de saúde dos próprios profissionais:

"A realidade na ponta está muito cruel, você está com uma faca no seu peito, atendendo de qualquer jeito, porque você já tem outro na porta. Ter espaço não só para discutir os casos, mas para nos discutirmos. Precisamos processar o sofrimento, a impotência, isso é saúde do trabalhador".

$\mathrm{Na}$ avaliação dos alunos, o curso operou nesse sentido e contribuiu para que eles se apropriassem de seu próprio trabalho, o que produziu alguma mudança na percepção da sobrecarga e do desgaste: "O curso funcionou como um espaço em que a gente podia discutir as angústias. Nós esperávamos esse apoio e saíamos muito fortalecidos".

\section{Sobre a gestão de si mesmo: o trabalho como obra}

Para além das mudanças nas concepções e nas práticas profissionais relativas à clínica, à gestão e ao trabalho em equipe, as narrativas evidenciaram efeitos do curso em outros âmbitos:

"Mudamos na nossa vida pessoal, na maneira de lidar com os filhos. Paramos de fragmentar o conhecimento, a vida. Muitas coisas que a gente apontava que os pacientes tinham que mudar, a gente também devia mudar".

Os alunos fizeram referência ao desenvolvimento de competências e habilidades relacionais, extrapolando a aquisição de conceitos e teorias:

"Alguns assumimos uma postura de mais liderança. Outros, que nunca manifestávamos opiniões, agora participamos das discussões. O curso potencializou nossa ação como pessoas. Conseguimos olhar e nos colocar na realidade do outro".

As narrativas apontaram que o curso exerceu uma função estruturante na identificação dos alunos com o próprio trabalho, e possibilitou a atribuição de um valor positivo para o trabalho na Atenção Básica, gerando gratificação e certa alegria:

"O curso foi um estímulo e uma motivação muito grande. Quando resolvemos um caso ou conseguimos pequenas coisas, nos damos conta de que fazemos diferença, que o nosso trabalho tem valor. Aquele preconceito, de sermos uma equipe que trabalha no 'postinho', diminuiu muito. Nos orgulhamos desses profissionais que trabalham com amor e dedicação, anônimos...".

Ao estimular o comprometimento dos alunos com o projeto institucional da Atenção Básica, o curso operou como um dispositivo de desalienação e restauração do trabalho em saúde como obra.

\section{Sobre o apoio Paideia como estratégia de formação: a experiência no coletivo}

As narrativas evidenciaram a intensidade da experiência coletiva de compartilhar reflexões, análises e intervenções, com destaque para a associação entre conhecimento e prática, proporcionada nas discussões de caso: "Quando a gente via como o colega lidava com o paciente, ia ficando mais fácil. Um livro, qualquer um pode pegar e ler. Mas a troca que fazíamos tem uma função que não existe em lugar nenhum". O espaço coletivo possibilitou aos alunos exercitarem estar em relação, apurar a sensibilidade e ampliar seu repertório analítico e operativo. A diversidade de temas abordados nas discussões de caso e a troca de experiências permitiram percorrer a amplitude do trabalho na Atenção Básica e favoreceram as ressonâncias da intervenção de cada aluno no processo de aprendizagem do grupo.

A ênfase no aspecto relacional foi apontada como algo que favoreceu a reflexão sobre si mesmo: 
"Escolhemos o caso com que tínhamos mais identificação e dificuldade, então fomos aprendendo a lidar com as nossas implicações". Valorizando a singularidade da experiência registrada pelo olhar e pela escuta do profissional e da equipe, os alunos puderam se situar a si próprios na relação, defrontando-se com seus preconceitos, angústias e defesas. O empenho em assegurar um setting protegido para a grupalidade resultou num espaço percebido como continente para que todos trouxessem as vicissitudes da prática, "as questões mais doloridas, sem medo da crítica".

\section{Discussão}

Observou-se que os efeitos do curso se situaram em três dimensões interdependentes: conhecimento; atitudes e posturas; e competências e habilidades.

A experiência de analisar e discutir a prática num espaço coletivo foi potente para modificar a relação dos alunos com o conhecimento. Eles assumiram a posição de quem constrói o conhecimento, ao equacionar conceitos e normas na compreensão do caso singular, compondo um saber interdisciplinar, ou seja, a própria práxis da saúde ${ }^{19}$.

Foi marcante a ampliação da capacidade reflexiva e analítica dos alunos. Reconhecendo a dimensão política da clínica, compreenderam as interligações entre modelos de gestão, organização dos serviços e práticas assistenciais, e questionaram-se sobre o que produzem na clínica. Aqui, trata-se da incorporação de conhecimentos, mas também de uma postura crítico-reflexiva diante do mundo e do papel social do profissional de saúde.

As intervenções junto ao caso de Dna. Ana revelam o desenvolvimento de competências e habilidades essenciais para uma clínica sensível à dimensão da subjetividade ${ }^{15}$. Arthur e sua equipe modificaram a relação com a paciente e sua família, o que foi sustentado a partir da compreensão da paciente a partir dos traços de sua história, que ela própria trouxe. Por meio da ampliação da escuta, da suspensão dos preconceitos e do reconhecimento dos afetos despertados, foi possível acessar seu sofrimento e suas necessidades, que ficavam encobertos pelo rótulo "poliqueixosa". Ao tomá-la como sujeito, com uma biografia singular, com desejos, potências e limitações ${ }^{17}$, a equipe pôde restabelecer o diálogo com ela e construir sentido para as propostas terapêuticas.

A estratégia de discussão de casos foi propícia para a compreensão sobre a relação terapêutica e entre a equipe, e para perceberem a si mesmos envolvidos nas tramas de afetos, poderes, saberes e interesses ${ }^{9}$. O compartilhamento de reflexões e experiências favoreceu a criatividade na composição das intervenções e a conexão entre o conhecimento e a prática, conferindo sentidos ao processo de ensino-aprendizagem ${ }^{10}$. Ao longo do acompanhamento dos casos foi possível aos alunos exercitarem sua capacidade de dialogar e negociar, tanto nas discussões do grupo, como na pactuação das propostas terapêuticas com usuários e equipe.

A metodologia do curso cumpriu o objetivo de desenvolver, junto aos alunos, maior capacidade de análise e intervenção para a construção de práticas ampliadas e compartilhadas em saúde ${ }^{1}$. Os alicerces da metodologia são a noção de experiência e as articulações entre teoria e prática, reflexão e intervenção. Mas, para além da dimensão operativa do método, integrando pensamento e ação, sua potencialidade está em propiciar a construção de sentidos às experiências ${ }^{24}$.

O apoio Paideia atua na interseção das dimensões analítica, técnica e política. Assim, destaca-se uma provocação feita por Freud ${ }^{25}$, ao se referir à psicanálise, à educação e à política como ofícios "impossíveis". Impossíveis porque incessantes, ou seja, em cada ato é preciso reinventá-las. Além disso, dependem de certa aposta, já que pretendem produzir mudanças. A natureza desses ofícios (e também o do apoiador) é, portanto, indeterminada e indeterminável.

Castoriadis ${ }^{26}$ discutiu o psicanalisar, o educar e o governar como atividades cuja finalidade é a construção da autonomia. Ressalta que, nesses campos, processo e resultado não estão desvinculados. Ou seja, a autonomia é o fim buscado, mas é somente por meio de seu exercício que ela se torna possível. Assim, entende-se que os resultados do processo formativo aqui apresentado se encontram na própria possibilidade dos sujeitos exercitarem sua autonomia, interrogarem os sentidos recebidos da tradição, da sociedade e da história pessoal e, desse modo, poderem construir maior capacidade para 
alterar suas práticas. Essa disposição para a interrogação não se realiza de uma vez por todas, mas deve ser incessantemente refeita, a fim de se recolocar continuamente em questão as certezas sob as quais a existência e o saber, os modos de ser e de agir se sustentam. Uma formação-Paideia, em suas conexões entre política, psicanálise e educação, e em sua íntima relação com a coprodução de sujeitos reflexivos e interventivos, necessita ser reafirmada cotidianamente.

\section{Colaboradores}

Os autores participaram, igualmente, de todas as etapas de elaboração do artigo

\section{Referências}

1. Campos GWS. Um método para análise e cogestão de coletivos. São Paulo: Hucitec; 2000.

2. Ministério da Saúde. Secretaria de Atenção à Saúde. Núcleo Técnico da Política Nacional de Humanização. HumanizaSUS: a clínica ampliada. Brasília (DF): SAS; 2004.

3. Campos GWS, organizador. A clínica do sujeito: por uma clínica reformulada e ampliada. In: Saúde Paideia. São Paulo: Hucitec; 2003. p. 51-67.

4. Figueiredo MD, Onocko Campos R. Saúde Mental na Atenção Básica à saúde de Campinas (SP): uma rede ou um emaranhado? Cienc Saude Colet. 2009; 14(1):129-38.

5. Tanaka OU, Ribeiro L. Desafio para a atenção básica da assistência em saúde mental. Cad Saude Publica. 2006; 22(9):1845-53.

6. Traverso-Yépez M, Morais NA. Reivindicando a subjetividade dos usuários da rede básica de saúde: para uma humanização do atendimento. Cad Saude Publica. 2004; 20(1):80-8.

7. Nuto SAS, Noro LRA, Cavalsina PG, Costa ICC, Oliveira AGRC. O processo ensinoaprendizagem e suas conseqüências na relação professor-aluno-paciente. Cienc Saude Colet. 2006; 11(1):89-96.

8. Souza NA. Formação médica, racionalidade e experiência. Cienc Saude Colet. 2001; 6(1):87-96.

9. Oury J. Itinerários de formação. Rev Prat. 1991; (1):42-50.

10. Mitre SM, Siqueira-Batista R, Girardi-de-Mendonça JM, Morais-Pinto NM, Meirelles $C A B$, Pinto-Porto $C$, et al. Metodologias ativas de ensino-aprendizagem na formação profissional em saúde: debates atuais. Cienc Saude Colet. 2008; 13(2):2133-44.

11. Figueiredo MD. A construção de práticas ampliadas e compartilhadas em saúde: apoio Paideia e formação [tese]. Campinas (SP): Faculdade de Ciências Médicas, Unicamp; 2012.

12. Cunha GT. Grupos Balint-Paideia: uma contribuição para a cogestão e a clínica ampliada na Atenção Básica [tese]. Campinas (SP): Faculdade de Ciências Médicas, Unicamp; 2009.

13. Furlan PG, Amaral MA. O Método de Apoio Institucional Paideia aplicado à formação de profissionais da Atenção Básica em Saúde. In: Campos GWS, Guerrero AVP, organizadores. Manual de práticas de Atenção Básica: saúde ampliada e compartilhada. São Paulo: Hucitec; 2008. p. 15-33. 
14. Campos GWS. Cogestão e neoartesanato: elementos conceituais para repensar o trabalho em saúde combinando responsabilidade e autonomia. Cienc Saude Colet. 2010; 15(5):2337-44.

15. Onocko Campos R. A gestão: espaço de intervenção, análise e especificidades técnicas. In: Campos GWS, organizador. Saúde Paideia. São Paulo: Hucitec; 2003. p. 122-49.

16. Nasio JD. Os grandes casos de psicose. Rio de Janeiro: Jorge Zahar; 2001.

17. Balint M. O médico, seu paciente e a doença. Rio de Janeiro: Livraria Atheneu; 1988.

18. Pichon-Rivière E. O processo grupal. São Paulo: Martins Fontes; 1985.

19. Denzin KN, Lincoln YS. Handbook of qualitative research. London: Sage Publications; 2000.

20. Gadamer H-G. Verdade e método I: traços fundamentais de uma hermenêutica filosófica. Petrópolis: Vozes; 2003.

21. Ricoeur P. Interpretação e ideologias. Rio de Janeiro: Francisco Alves; 1990.

22. Minayo MCS, Souza ER, Constantino P, Santos NC. Métodos, técnicas e relações em triangulação. In: Minayo MCS, Assis SG, Souza ER, organizadores. Avaliação por triangulação de métodos: abordagem de programas sociais. Rio de Janeiro: Fiocruz; 2005. p. 71-103.

23. Ricoeur P. Tempo e narrativa. Campinas: Papirus; 1997. Tomo I.

24. Bondía JL. Notas sobre a experiência e o saber de experiência. Rev Bras Educ. 2002; (19):20-8.

25. Freud S. Análise terminável e interminável (1937). In: Salomão J, organizador. Rio de Janeiro: Imago; 1975. p. 239-88. Edição standard brasileira das obras psicológicas completas de Sigmund Freud, v. 23.

26 Castoriadis C. Encruzilhadas do labirinto. Rio de Janeiro: Paz \& Terra; 1987.

Figueiredo MD, Campos GWS. El apoyo Paideia como metodología para los procesos de formación en salud. Interface (Botucatu). 2014; 18 Supl 1:931-43.

El artículo analiza el apoyo Paideia como marco de referencia pedagógico en un proceso de formación en salud, cuyo diseño combinó ofertas teóricas, discusión de casos y intervenciones. Se evaluaron los efectos de este proceso de formación en las prácticas de los profesionales, con respecto al enfoque de la subjetividad. El material empírico fue construido a partir de: grupos focales, análisis de un caso clínico y discusión con el equipo responsable por el caso. Se observaron cambios en la práctica clínica, de gestión, y en el "manejo de sí". Los profesionales desarrollaron competencias técnicas, éticas y relacionales para actuaren las múltiples dimensiones de los sujetos. Se concluye que el énfasis en el intercambio de experiencias y en la articulación entre reflexión e intervención contribuye para que la formación produzca cambios en los sujetos, en las prácticas y en los servicios de salud.

Palabras clave: Método Paideia. Apoyo institucional. Formación. Clínica ampliada. Subjetividad.

Recebido em 14/05/13. Aprovado em 22/08/14. 
